\title{
SYMBOLIC PROTECTION OF ANIMALS
}

\author{
AGNIESZKA BIELSKA-BRODZIAK ${ }^{1}$, MARLENA DRAPALSKA-GROCHOWICZ ${ }^{2}$ \\ AND MAREK SUSKA ${ }^{3}$ \\ ${ }^{1}$ University of Silesia in Katowice, Faculty of Law and Administration, ul. Bankowa 11, Katowice, Po- \\ land. ORCID: 0000-0002-9926-6436, Email: agnieszka.bielska-brodziak@us.edu.pl \\ ${ }^{2}$ University of Silesia in Katowice, Faculty of Law and Administration, ul. Bankowa 11, Katowice, Po- \\ land. ORCID: 0000-0002-8602-2918, Email: mdrapalska@gmail.com \\ ${ }^{3}$ University of Silesia in Katowice, Faculty of Law and Administration, ul. Bankowa 11, Katowice, Po- \\ land. ORCID 0000-0002-0950-5588, Email: m.suska@poczta.onet.pl
}

ABSTRACT: The purpose of this article is to attempt to understand some institutions of Polish animal protection law using the concept of "symbolic legislation". The law is symbolic when, despite apparently ordering or prohibiting certain behaviours, it does not establish effective mechanisms for enforcing these obligations. The authors on selected examples show that in the field of animal protection law, there are no such symbolic solutions. At the same time, they indicate that not all of these situations deserve a negative assessment and come to the conclusion that the "symbolism" of regulation is not always the fault of the legislator himself. The concept of symbolic legislation allows a better understanding of how a legal act can affect social reality among others, where there is a strong need for social education, such as in the field of animal protection.

KEYWORDS: symbolic legislation, animal protection, legal interpretation, practical dimension of law, legislative process

The scientific and journalistic discourse on law-making has often seen opinions that specific provisions are "dead", "fiction" or "ineffective". In the theory of law, such situations are analysed using the concept of symbolic legislation. The attribute "symbolic" correctly renders the essence of the issue, for it applies to something which "has little practical influence on a situation" ${ }^{1}$. Symbolic provisions or legislation are mere substitutes of "real law", and not an effective instrument for regulation of the social order. The symbolic legislator creates orders and prohibitions, but at the same time

\footnotetext{
${ }^{1}$ Cambridge Dictionary. Retrieved August 24, 2019 (dictionary.cambridge.org, entry symbolic).
} 
does not aim to establish effective mechanisms for the enforcement thereof, and does not strive to ensure that the addressees thereof will fulfil the obligations laid down in the law (van Klink 2016: 20-21); symbolic provisions are not an adequate measure to achieve the officially proclaimed goal (van Klink: 19) ${ }^{2}$. As such, they do not have any actual and direct impact on the behaviours of their addressees (cf. Tushnet and Yackle 1997: 3).

\section{I. ‘BAD’ AND ‘GOOD’ SYMBOLIC LEGISLATION}

While symbolic legislation is usually viewed negatively in the science of law, other, more favourable opinions on this phenomenon can be found as well. Accordingly, we shall speak of "bad" and "good" symbolic legislation. Prima facie, it appears that the criterion behind this division is the attitude towards the proclaimed goal - if the legislator actually has no intention of achieving it and instead strives to accomplish other, extra-legal tasks, it will be an example of bad legislation. Conversely, if the legislator demonstrates care of the goal proclaimed, but fails to implement provisions to ensure the accomplishment thereof, it may be a case of good symbolic legislation. In fact, however, the problem is far more difficult, if only because it is hard to objectively determine what the legislator's attitude to the proclaimed goal is and to establish the motives that guided the members of the legislature.

Symbolic legislation - the kind that can be described as "bad" - is created to achieve various extra-legal objectives. At this point, we shall focus on two. First of all, laws can be used by members of the legislature (the parliamentary majority) as a means of demonstrating their strength and the ability to control the external world. This type of demonstration can be useful for calming down public opinion in crisis situations ${ }^{3}$. Alternatively, for merely increasing one's chance of success in the next election (van Klink 2016: 23). Indeed, voting for the "realisation" of noble ends can bring several political gains at minimum cost (Dwyer 1990: 233) - the ostensible nature of a reg-

\footnotetext{
${ }^{2}$ It appears that this is what Marek Smolak had in mind when explaining the concept of "imitative statutes", as illustrated by the example of Art. 2(3) of the so-called remedial enactment (Act of 22 December 2015 amending the Law on the Constitutional Tribunal, JoL of 2015, item 2217), which stipulates that the dates of hearings during which petitions are examined shall be appointed following the chronological order in which cases have been filed and received by the Constitutional Tribunal of Poland - starting from the oldest ones. The author believes that this type of provision could not have contributed to achieving the objective proclaimed by the legislature, namely streamlining the work of the Tribunal. At the same time, M. Smolak provides a number of arguments to demonstrate that enactment of imitative statutes is immoral. See. Smolak 2016.

${ }^{3}$ An exciting example of this type of provisions from the Polish legislative practice were $\S \S 4$ and 5 laid down in Art. 25 of the Act of 6 June 1997 - the Criminal Code (currently Art. 231b of the Criminal Code), introduced as a reaction to the shocking murder of a police officer intervening to defend public property. According to Celina Nowak, this was an example of a "solution that guaranteed sentimental and emotional satisfaction” and, as explained by Włodzimierz Wróbel “(...) a response to a specific event causing social emotions. In most cases, these events have a special character, and proposals for legislative changes emerge even before the perpetrators are held to account by court. On the one hand, the enactment of new laws is supposed to demonstrate that politicians care for citizens' safety, and on the other one, it is a symbolic punishment of the offence by the legislator" (Wróbel 2009: 105-106).
} 
ulation weakens the intensity of protests on the part of those addressees who could be affected by the effects of the new provisions. One case discussed in this context in literature is the American Clean Air Act. In this case, members of the Congress voted in favour of a regulation that was a message of unequivocal support for the protection of public health and natural environment and an expression of objection to "trading life for dollars". At the same time, however, they delegated the requirement to set the extremely restrictive and costly norms for emissions of air pollutants on an external entity - the governmental Environmental Protection Agency (Dwyer 1990: 237-239). According to J.P. Dwyer, these types of provisions should not be read literally, as if the Congress had actually required the Agency to draw up a strict list without regard to economic and social costs. Instead, the regulation was a general signal: on the one hand, to the general public, that the legislature is aware of the severe threat to public health and environment, and on the other one - to the EPA, so that the Agency would make a dedicated effort to achieve adequate supervision over the emissions of these substances (Dwyer 1990: 250).

The case referred to above also exhibits the second reason for the enactment of symbolic laws: confirmation of the value system defended by a particular group (van Klink 2016: 23) ${ }^{4}$. Here, the legislator expresses official approval for certain values but does not provide any real safeguards for the realisation thereof. This act of affirmation can, at the same time, be motivated by an attempt to take control over a crisis social situation or an attempt to increase one's election chances. It, therefore, does not have to be the case that the two motives for the enactment of bad symbolic legislation are disjunctive.

Why are symbolic laws viewed negatively? Unenforceable provisions can pose a threat to the authority of law (Niesiołowski 2017: 599). Indeed, if a certain legal institution is ineffective, this undermines social trust in the effectiveness of law as such, and if - for whatever reason - judges or government officials have to "enforce" provisions that are in their literal form unenforceable, they may be triggered into doing two sorts of things - both having negative consequences. First of all, a judge or government official may eschew issuing a decision or delay doing so, in the hope that the provisions will change in the meantime. Secondly, the law enforcement authority may attempt to creatively interpret the current symbolic provisions and assign them a more functional form (having little to do with their literal wording). The rewriting of provisions of law by law enforcement authorities certainly does not have a positive influence on the feeling of legal security of citizens. It can furthermore decrease the quality of public debate due to the judges of government officials concealing the true

\footnotetext{
${ }^{4}$ In a similar context, "symbolic crusades" such as the alcohol prohibition in the USA have been discussed by L.W. Koch and J.F. Galliher (Koch, Galliher 1993: 327). These crusades are supposed to symbolise the moral superiority of a lifestyle promoted by particular social groups; if these are reflected in the legislation, this will undoubtedly mean that the proposed lifestyle has been acknowledged and accepted by the legislator. Van Klink mentions the third reason behind the creation of this type of legislation, one that appears in some ways related to expressing affirmation for a system of values held by a specific group - resolution of conflicts between social groups or political parties. See van Klink 2016: 23.
} 
motivations behind their actions (Dwyer 1990: 281-282). For how many law enforcement authorities will be ready to admit that they reject the literal meaning of a provision and use it to create a new legal norm (in a situation when law-making is not a competence vested in the law enforcement stage)?

As already mentioned, the science of law is also no stranger to more favourable views on symbolic legislation. Indeed, "symbolic" may apply to not only the absence of a "real meaning" of provisions of law, but also to provisions "symbolizing" something more important: the axiological choices of the legislator (van Klink 2016: 20-21). Good symbolic legislation may be a tool for raising the awareness of the existence of certain problems among citizens. It can also build ground for deep and lasting social changes. Here, the legislator abstains from issuing classic prohibitions backed up with severe sanctions. Instead, he creates regulations geared to changing behaviours not through fear-inducing rhetoric, but through raising awareness through debates and mutual interactions between sometimes radically different social groups (cf. van Klink 2016: 19-20). Such symbolic laws are so general in nature that they in fact merely establish the framework for further social discourse - understood as a debate that will take place at the stage of application of the law and not its creation. Vague terms (e.g. general clauses) intentionally used in such legislation have to be filled with content what is more, the legislator allows the content to change as social beliefs do. Symbolic legislation thus becomes a "vocabulary that affects the way in which legal and political actors perceive reality. Reality is accessed through the concepts and distinctions provided by the law" (van Klink 2016: 25).

Good symbolic legislation can be treated as a way of determining the direction of a state's policy, and as a moral and educational impulse for both those who obey and break the law, through the determination of what constitutes a publically acceptable/ unacceptable behaviour. This can lead to long-term changes in both the law and society, without having to resort (despite the absence of) to mechanisms for "enforcing” changes using sanction instruments (Baum 2011: 113). In this context, legislation means sending signals to society, showing that it is morally essential and considered legitimate by the legislator. It is, therefore, possible that it is not about whether this kind of legislation "works", but whether the process of law-making affects the social discourse (and thus constitutes a sort of signal that triggers the search for new collective solutions).

This does mean that the legislator, using a thus understood symbolic legal act, always declares values that without any doubt, should be considered as "noble". The implied, moral layer of legal acts can, in fact, be a tool for doing symbolic harm to social minorities. In this context, it is worth discussing a case from the British law concerning pre-implantation genetic diagnosis and in vitro fertilisation. The legislator determined therein that "healthy" embryos should always be picked for implantation before the "sick" ones, which followed from poorly-justified concerns that persons with a disability (e.g. deafness) could prefer to have children similar to themselves in this regard. According to J. L. Scully, the provision requiring that preference in each case be given to a "healthy" embryo is at the same time a message that the legislator considers a life with a disability (e.g. deafness) to be a poor quality life, which may 
spark a vivid and legitimate outcry among many deaf people (Scully 2011: 206-207).

To recapitulate on what has been discussed herein so far, we should stress that the symbolism of law-making may have two different aspects. Firstly, there are no "hard" guarantees for the enforcement of the law; this aspect is common for both the "bad" and "good" symbolic legislation. Secondly - it is about being a vehicle for specific values. Given the explicitly stated sanction, nobody will consider the provision laid down in Art. 148 § 1 of the Polish Criminal Code $^{5}$ To be an example of symbolic legislation, although it undoubtedly constitutes an axiological declaration on the part of the legislator. The absence of typical mechanisms for the enforcement of obligations is, therefore, a requisite condition if one is to apply the notion analysed herein in the process of assessment of any regulation. However, it does not necessarily follow that if the first condition is met, and so is the second one - a provision symbolizes certain vital values - the provision in question will automatically merit being labelled as good symbolic legislation. In fact, it is far more complicated. It appears that the assessment of a specific law or provision will, on the one hand, depend on the values accepted by the person doing the assessment, and on the other one - on its practical effects (van Klink 2016: 27-32). A significant role in this regard can also be played by expectations as to what outcomes a regulation is supposed to bring 6 .

It is not easy to determine whether we are dealing with bad or good symbolic legislation. This does not mean, however, that discussions on this cannot be based on empirically verifiable arguments. After all, one can predicate, with higher or lower probability, how the promulgation of a law affected the social awareness or whether the overly ambitious or pointless from the start attempt at the "realisation" of a specific objective by the legislator did not result in the deprivation of the allegedly affirmed values of any and all protection. It has to be noted that the assessment of an instance of legislation or provision will frequently depend on what its application in practice turns out to be like. Indeed, it is often the practice that determines whether an attempt on the part of the legislator will be considered as good or bad symbolic legislation, for practice can in many cases "revive" provisions intentionally created to play the role of "dead law" and conversely - practice can "kill" a law that was intended by the legislator to launch a debate on fundamental values.

To conclude this part of the analysis, it is worth pointing out that the concept of symbolic legislation is associated with another, historically older, construction, namely the leges imperfectae. Let us then briefly outline the essence of this type of legal

\footnotetext{
${ }^{5}$ Act of 6 June 1997 - The Criminal Code (uniform text JoL of 2018, item 1600, as amended). Pursuant to Art. 148 § 1 thereof, "Whoever kills a human being shall be subject to the penalty of deprivation of liberty for a minimum term of 8 years, the penalty of deprivation of liberty for 25 years or the penalty of deprivation of liberty for life".

${ }^{6}$ With reference to the US Congress ignoring the economic costs of air protection (the aforementioned Clean Air Act case), a proponent of environmental protection could argue that this was an instance of affirmative legislation, worthy of a public support of values. If these provisions triggered social debate and drew attention to the problem of emission of pollutants to the air, they could be conceived as good symbolic legislation. However, if the person doing the assessment expects the formulated prohibitions to be read literally, he is bound to view these types of provisions negatively.
} 
solutions. When the leges imperfectae are described as norms without sanction, it is pointed out that the very term "legal sanction" is polysemous (...) taking into account the leges imperfectae; it is most appropriate to regard a legal sanction in its linguistic meaning, namely as a prognosis of negative consequences in the event of behaviours violating the law" (Niesiołowski 2017: 598). Where the legislator does not provide for such negative consequences, we can speak of lex imperfecta. When this is the case, we usually have to do with a conscious forgoing of a sanction: the legislator does not make a mistake, but instead consciously decides to forgo a sanction as "in certain spheres subject to legal regulation, establishing sanctions in provisions of law is, for various reasons, impossible, unnecessary, or not conducive to making the norms effective” (Jabłońska-Bonca 1984: 152)7. Irrespective of the above, the term leges imperfectae is not used with reference to norms which, although some sanction (understood literally) is provided for, are not - for various reasons - enforced in practice. Where

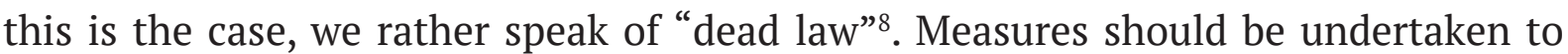
eliminate such regulations from the legal system, as they pose a significant threat to its authority and lead to the formation of undesired attitudes (Niesiołowski 2017: 599). Seldom conducted, analyses of the leges imperfectae concentrate on an indication of conditions where these types of provisions can be deliberately and legitimately created by the legislator. It can, therefore, be presumed that if the leges imperfectae at the same time refer to specific fundamental values, they can resemble good symbolic legislation. Meanwhile, "dead law", when contrasted with the leges imperfectae, would bear a resemblance to negative symbolic legislation. The above, however, are merely ancillary observations, and the establishment of more exact relations between symbolic legislation, the leges imperfectae and other notions (such as soft law ${ }^{9}$ ) requires in-depth analyses, which goes beyond the framework of this article.

\section{SYMBOLIC AND REAL LAYER OF THE PRINCIPLE OF DEREIFICATION}

Legal acts that determine the status of animals often express loud axiological declarations that can be read as an expression of people's concerns as to the wellbeing of animals. Needless to say, this is most visible in those legal acts that establish animal protection for humanitarian reasons, and not e.g. due to their economic value. The most prominent example of such a declaration is the provision of Art. 1(1) of the Animal

\footnotetext{
7 "(...) creation of legal norms in the form of the leges imperfectae can be rational. In constitutional law, safeguarding all norms laid down in the Constitution with a legal sanction can prove impossible, as in the case of the so-called programmatic norms. It is important in this regard to not that a major role in constitutional law is played by political sanctions. Meanwhile, in family and guardianship law, the establishment of legal sanctions many prove futile" (Niesiołowski 2017: 600).

${ }^{8}$ On the other hand, however, it is argued that it would be an overstatement to say that a provision without a sanction is a provision that the legislator failed to provide with effective enforcement mechanisms. As J. Jabłońska-Bonca has pointed out, the exact opposite is the case: the legislator should create such provisions only where he expects a norm to be useful even without sanction. See. Jabłońska-Bonca 1984: 164.

${ }^{9}$ More on this see e.g. Skuczyński (2008); Bańczyk (2016).
} 
Protection Act ${ }^{10}$, which expresses the so-called principle of dereification: "The animal, as a live creature, capable of suffering, is not a thing. Man should respect, protect, and care for it". What is essential, the declarations referred to above are expressed in the body of the text of legal acts, which highlights that they are intended to express binding rules of practice. The Polish law-making practice is familiar with preambles as those parts of legal acts that, on the one hand, make it possible for the legislator to present values he holds dear ${ }^{11}$, and on the other one - that are not considered to be as binding as the body of the text ${ }^{12}$. This, even more, triggers questions as to the symbolic and "real" layer of provisions containing axiological declarations. Are these types of provisions effective in affecting the relations between humans and animals outside "the world postulated by the law"13? Do they actually improve the situation of animals, or are they merely a fig leaf, partly concealing human supremacy over animals?

The quoted above Art. 1(1) of the Animal Protection Act is a provision that can be seen as an attempt on the part of the legislator to re-establish relations between people and animals. It is worth noting that the placement of this provision in such a prominent section of the act - one intended as a "constitution" ${ }^{14}$ For the legal status of animals at that - is indicative of the legislator's intention for the principle of dereification to be taken into account not just in the process of application of the Animal Protection Act and its secondary legislation but also all the other legal acts. The provision laid down in Art. 1(1) of the Animal Protection Act provides, in most general terms, a model for the treatment of animals that must be taken into account by courts and public administration authorities in the assessment of specific behaviours towards animals. The axiological weight of this provision is undeniable: in the value system of the legislator, it is unacceptable to treat living creatures, capable of suffering, in the same way as entities that do not have these attributes. Through this provision, the legislator furthermore expresses his moral disapproval of views that man's control over an animal is no different than his control over a thing. The legislator's position is clear: no animal ${ }^{15}$ Is a thing, regardless of the extent to which it can feel

\footnotetext{
${ }^{10}$ Animal Protection Act of 21 August 1997 (uniform text JoL of 2019, item 122, as amended).

${ }^{11}$ Recent years have brought a renewed increase in the popularity of preambles in the Polish law-making - see e.g. the preamble to the Act of 16 November 2016 on the National Fiscal Administration (uniform text JoL of 2019, item 768, as amended), or the preamble to the Act of 15 September 2017 on the National Freedom Institute - Centre for the Development of Civil Society (uniform text JoL of 2018, item 1813).

${ }^{12}$ Opinions on the issue of a normative character of a preamble of a legal act is presented e.g. in Stefaniuk 2010.

${ }^{13}$ To use a term coined by M. Matczak (see Matczak 2019).

${ }^{14}$ The use of this term to denote a particular statute (or collection of statutes) of a critical importance for a specific scope of matters has also been on the rise in recent years. Examples include the "Constitution for Business” (https://www.gov.pl/web/przedsiebiorczosc-technologia/konstytucja-biznesu) or the "Constitution for Science" (https://konstytucjadlanauki.gov.pl).

${ }^{15}$ While the Animal Protection Act regulates the "treatment of vertebrate animals" (Art. 2(1), the principle of dereification can be applied more extensively, for it should be emphasized that the legislator in Art. 1(1) does not stipulate that only vertebrate animals are not things; furthermore, in the structure of the Animal Protection Act, this provision comes before a provision that limits the scope of application
} 
suffering. As a side note, we could ask whether a man can assess these capabilities and decide what "pain and suffering threshold" is sufficient for an animal to be granted this special status (Goettel 2013: 46). It is worth noting that further in the act the legislator supplements provision of Art. 1(1) with the requirement of humane treatment of animals, understood as treatment that factors in an animal's needs and ensures that it receives care and protection ${ }^{16}$.

The principle of dereification triggers theoretical-legal disputes as to its impact on animal rights. As Ewa Łętowska points out, "the point of the entire operation [dereification] depends on whether law enforcers are ready, eager, and sensitive enough to use this provision correctly (Łętowska 1997: 86). Art. 1(1) of the Animal Protection Act in itself does not require the public to give up exploitation of animals altogether in various fields. Instead, it constitutes a kind of agreement (or rather a public promise, for it is difficult in this case to speak of an agreement between two parties) that civilizes the way people behave towards animals (Pazdan 2012).

The traditional treatment of animals as things was connected e.g. with the fact that they were a subject of civil-law transactions. One may question whether putting an equation mark between animals and things were "a direct, consciously accepted philosophical-axiological consequence reflecting the overall attitude of people towards animals" (Łętowska 1997: 81). The elaboration of the principle of dereification was a confirmation of quite universal and well-established social tendencies that manifested themselves in the development of a positive attitude towards animals ${ }^{17}$. On the other hand, some authors view the introduction of Art. 1(1) of the Animal Protection Act as a revolutionary breaking point, radically revising the relations between people and animals. Nevertheless, Dorota Probucka cools down over-optimism and argues that the Animal Protection Act is just the beginning of a breakthrough and proof that legal protection of animals is insufficient and ultimately serves people's interests (Probucka 2015: 306).

It should be stated that the principle of dereification has all it takes to be considered as an example of good symbolic legislation. It is beyond any doubt that it expresses the legislator's affirmation for specific values - ones that, as it appears, are highly regarded by the society at that. At the same time, it is a very general provision that in itself does not establish any sanctions for its violation. Admittedly, deciding

\footnotetext{
of the Act. We believe it indicates that only the provisions of the Animal Protection Act that come later (starting from Art. 2) have a thus narrowed down subjective scope.

${ }^{16}$ Art. 5 in connection with Art. 4 point 2 of the Animal Protection Act.

${ }^{17}$ Its introduction into the Polish legal system meant copying positive legislative trends that had earlier appeared in the legislation of other European countries. For instance, Germany has a relatively long-standing tradition of regulating the legal status of animals. The National Socialist Law for the Protection of Animals (1933) remained in force after the World War II virtually unchanged. A new law was enacted as recently as 1972 and has remained in force to this day (Tierschutzgesetz). Dereification of animals was conducted through the introduction of Art. 90a, explicitly stating that animals are not things, to the German Civil Code (BGB) in 1990. However, the most significant change as regards humanitarian protection of animals was the introduction of animal protection into the German Basic Law (Grundgesetz) in 2002. The same was done in Austria, where Art. 285a was added to the ABGB (Nazar 2002: 129-130).
} 
on whether an animal has been treated as a thing could prove to be a difficult challenge for both courts and public administration authorities. It is emphasized in the science of law that principles express values protected by the legislator and, by their very nature, are meant to be used jointly with other provisions, for instance, those that impose certain specific obligations. Therefore, the principle of dereification is predominantly a position that law enforcers must take into account while interpreting other provisions. This can lead to the adoption of those interpretive hypotheses that, to a more significant extent safeguard the wellbeing of an animal. At the same time, the wording of the principle is general enough to ensure an ongoing debate on what the assertion that an animal is not a thing means, and the convictions as to the scope of protection that must accordingly be awarded to an animal can evolve.

At the same time, it should be pointed out that the legislator expressly entrusted the interpretive community with leading the discussion on relations between people and animals. More specifically, in the provision laid down in Art. 1(2) of the Animal Protection Act, the legislator determined that in matter not provided for in the Act, provisions concerning things shall apply - subject to the provision that they should be applied "accordingly". As agreed in the theory of law for many years now (Nowacki 2003: 455-457), this means either direct application of specific provisions, with necessary modifications, not applying them at all. Which of the legal institutions applicable to things can be applied to animals, which ones require codification, and which ones cannot be applied at all, is to be decided by the interpretive community. As the legislator was not ready to resolve specific problems, he only created a general framework for the discussion that must proceed on an ongoing basis among both law enforcement authorities and citizens.

In the existing practice of application of law, the principle of dereification has found reflection in the legal protection of domestic animals. This symbolic declaration increasingly pervades into case-law, as exemplified by judgments where domestic animals were treated as quasi family members ${ }^{18}$. However, the legislator's declaration is of marginal importance when it comes to farm animals. For how can one reconcile the dereification of animals and the requirement for humanitarian treatment of animals with today's industrial breeding standards? After all, we are talking here about animals that spend their entire lives in captivity, kept in limited space, often without access to natural light, unable to satisfy their basic species-specific needs. We are talking here about separating animals from their mothers, beak trimming, castration without anaesthesia, or animals waiting in horror to be slaughtered. Although, as per the legislator's will, these animals, too, are not things, it is not easy to name significant differences between them and things. They are traded, are in an economic relationship with man, and this relationship determines their life (cf. Breczko 2013: 22). In this case, the principle of dereification has in fact been labelled as "legal fiction" (Probucka 2015: 306). The principal goal of the numerous regulations concerning farm animals is not to ensure they have right living conditions, but to safeguard agricultural production

\footnotetext{
${ }^{18}$ Judgment of the Regional Court in Krakow of 7 September 2017, II Ca 1111/17; Judgment of the Regional Court in Krakow of 22 November 2016, II Ca 1883/16.
} 
and protect human life ${ }^{19}$. This is a sad, shameful, and often cruel face of the noble idea of dereification species other than human.

\section{PROHIBITION ON TRANSPORTING AND KEEPING LIVE FISH WITHOUT WATER}

In addition to the highly general principle of dereification, the Animal Protection Act introduces a number of obligatory modes of treatment, specified in great detail, protecting different aspects of the wellbeing of animals. In particular, this law prohibits animal abuse, understood as "inflicting or consciously permitting the infliction of pain and suffering" ${ }^{20}$. Violation of this prohibition constitutes an offence punishable by deprivation of liberty for up to 3 years ${ }^{21}$, and if the perpetrator acts with particular cruelty - the penalty is between three months and five years of deprivation of liberty ${ }^{22}$. The legislator, most likely fearing a situation where courts would excessively strictly interpret the criteria of this prohibited act (and thus distort the idea of humanitarian protection of animals ${ }^{23}$ ), decided to use a detailed, but at the same non-exhaustive list of actions that must be considered as animal abuse. This can be indicative of the legislator's determination to enact "hard" guarantees for a minimum level of protection of animals against pain and suffering, independent of current convictions and social or individual interests. One of such exceptional cases of animal abuse has been named in Art. 6(2) point 18 of the Animal Protection Act - it is transport or keeping of live fish for sale without sufficient amounts of water to allow breathing ${ }^{24}$. Interestingly, at first glance, this prohibition appears to have significant potential in terms of affecting the reality - after all, we are talking here about an offence punishable by a severe penalty and at the same time one that is quite simple from the perspective of its detection and proving. While it is evident that doubts may arise as to how, in the light of the vague

\footnotetext{
${ }^{19}$ For instance, regulations concerning farm animals focused on the production of food (Chapter 3, Art. 12-14 of the Animal Protection Act, Chapter 10 [Animal slaughter, putting animals to death, controlling animal populations], Art. 33-34 of the Animal Protection Act; Act of 29 June 2007 on Animal Breeding and Reproduction (JoL of 2017, item 2132); Act of 22 July 2006 on Feed (JoL of 2019, item 269); Act of 10 December 2003 on Veterinary Control in Trade (JoL of 2019, item 475); Act of 29 January 2004 on Veterinary Inspection (JoL of 2018, item 1557); Act of 25 August 2006 on Food and Nutrition Safety (JoL of 2018, item 1541).

${ }^{20}$ Art. 6(1a) and 2 of the Animal Protection Act.

${ }^{21}$ Art. 35(1a) in connection with point (1) thereof.

${ }^{22}$ Art. 35(2) in connection with point (1a) thereof.

${ }^{23}$ Interestingly, the legislator did not use a similar technique with respect to the abuse of a person as referred to in Art. $207 \S 1$ of the Act of 6 June 1997 - the Criminal Code (uniform code JoL of 2018, item 1600 , as amended): whoever mentally or physically mistreats a person close to him, or another person being in a permanent or temporary state of dependence to the perpetrator, shall be subject to the penalty of deprivation of liberty for a term of between three months and five years. On the concept of "abuse" about animals and people (see Więckowska 2017: 156-160).

${ }^{24}$ The prohibition was introduced into the Animal Protection Act by an amendment that entered into force on 1 January 2012 (JoL of 2012, item 1373). Initially, its wording carried an obvious legislative error, for it prohibited the transport of keeping of live animals for sale without sufficient amounts of water to prevent breathing.
} 
criterion of "without sufficient amounts of water to allow breathing", one should treat borderline cases, it appears, though, that in this regard one could rely on evidence from an opinion issued by experts.

The type of animal abuse discussed above obviously has its origins in the omnipresent in Poland retail sale of live carps during Christmastime. Carrying fish in plastic bags, without water, not only causes them stress due to taking them away from their natural environment but - most of all - causes them suffering due to difficulties breathing. This way of transporting may lead to a slow and painful death of fish as a result of suffocation. A similar assessment must be made of keeping excessive numbers of fish in barrels or fish tanks, prior to selling them to customers.

It should be pointed out that each year the Chief Veterinary Officer issues guidelines on how to treat live fish meant for retail sale. The document lays down "good practices" for the sale of live fish. The guidelines for the period 2012-2017 provided, among other things, that one of the acceptable methods for transporting fish is transport without water, provided that packing requirements are met. The packaging was supposed to allow gaseous exchange, which is possible when the packaging does not come into contact with the animal's skin (as is the case with plastic bags) or has elements that separate the animal's body from the surface of the packaging. Furthermore, the packaging cannot be closed (tied). Pursuant to the guidelines, these requirements are met by bags equipped with a ribbed container or properly perforated plastic inlay, placed around the body of the fish. Such methods for the transport of fish are nevertheless in contradiction to not just current knowledge on whether fish feel pain ${ }^{25}$, but also to the wording of Art. 6(2) point 18, which expressly sets out the obligation to transport fish in a sufficient amount of water to allow breathing. The guidelines by the Chief Veterinary Officer undoubtedly largely contributed to the prohibition in question becoming a dead law. A document of this type is not a source of generally applicable law, and its interpretation should definitely not be in contradiction to the Act. However, these guidelines, through their wording and the fact that was endorsed by a central government authority, became a sort of excuse for large retail establishments, used to justify measures contravening the Animal Protection Act.

It is beyond any doubts that the prohibition of transport of live fish or keeping of live fish for sale without sufficient amounts of water to allow breathing has a symbolic value, especially if we consider how widespread it was prior to the introduction of the prohibition. In doing so, the legislator expressed his moral condemnation of these sorts of practices and equated them - in terms of the applicable penalty - with such acts as animal abandonment (especially abandonment of a dog or cat) by its owner, organisation of animal fights, or sexual intercourse with an animal ${ }^{26}$. At the same time, however, the real relevance of this prohibition was marginal although - as already mentioned - violations of these sorts of prohibitions do not seem difficult to detect and prove. In fact, it appears that the reason why the provision in question had little

\footnotetext{
${ }^{25}$ Opinion of the Museum and Institute of Zoology of the Polish Academy of Sciences of 15 March 2010 on the carp's ability to feel pain.

${ }^{26}$ Art. 6(2) point 11, 15 and 16 of the Animal Protection Act.
} 
but symbolic significance was firstly prevalence of the issue and social acceptance of it, and secondly - the attitude of law enforcers. An extraordinary example of this sort of attitude was the guidelines by the Chief Veterinary Officer, which ignored the substance of the prohibition introduced by the legislator to safeguard particular economic interests. However, it seems that the provision discussed herein may actually gain real - not just symbolic - relevance, thanks to the judgment of the Supreme Court of 13 December 2016 ${ }^{27}$. Therein, the Court considered that transport and keeping of carps without water constitutes animal abuse even though the acts had been committed before the legislator added the prohibition to the list of distinctive forms of animal abuse. Regardless of that, this kind of treatment of fish fulfils the general criteria of "inflicting or consciously permitting the infliction of pain and suffering".

A question that should be asked as regards the case above is whether the legislator from the very beginning strived to establish a merely symbolic provision (in the case of which penal sanction was only intended to strengthen the symbolic message), or whether the provision only becomes symbolic legislation in the process of application of the law. The requirement to provide live fish with the right transport and keeping conditions is not an excessive burden, impossible to carry out by business entities and customers. The sanction for failure to comply with the requirement is not impossible to enforce, either. Hence, it is rather a case where the provision was intended by its authors to have an actual and direct impact on the reality but transforms into symbolic regulation through the practice of application of the law. The creation of the prohibition referred to above had initially significant potential in terms of raising social awareness of the ability of live fish (carps in particular) to feel pain in an environment without water. However, the power of this message significantly decreased due to the official, expressly stated the position of a public authority, which makes it legitimate to speculate that perhaps the symbolic message may, too, have become "blurred" by now. Nevertheless, as already mentioned, this is not irreversible - the provisions referred to above can improve its actual relevance in the course of evolution of judicial decision-making practice.

\section{PROHIBITIONS CONCERNING ANIMAL TETHERING}

Another requirement that can be analysed from the perspective of the concept of symbolic legislation has been laid down in Art. 9(2) of the Animal Protection Act. It stipulates that domestic animals must not be permanently tethered for more than 12 hours a day or in a way that causes bodily harm or pain and prevents necessary movement. The length of the tether must not be shorter than 3 metres. Violation of this requirement constitutes a misdemeanour subject to the penalty of the arrest of a fine of up to 5.000 zlotys $^{28}$. In the symbolic layer, these provisions express the legislator's moral disapproval of improper tethering of domestic animals, which seems consistent with

\footnotetext{
${ }^{27}$ II KK 281/16.

${ }^{28}$ Art. 37(1) of the Animal Protection Act in connection with Art. $24 \S 1$ of the Act of 20 May 1971 - The Petty Offence Code (uniform text, JoL of 2019, item 821, as amended).
} 
social assessment of this phenomenon ${ }^{29}$. As a side note, it should be added that no such condemnation was expressed by the legislator with respect to similar practices involving farm animals such as cows or horses.

From the perspective of humanitarian animal protection, the axiological declaration expressed in Art. 9(2) of the Animal Protection Act, deserves full support. At the same time, this provision prima facie establishes very precisely formulated conditions keeping domestic animals and is additionally safeguarded by a penal sanction - it can, therefore, be expected to shape the way people behave towards animals directly. In reality, however, the possibilities for its enforcement are so limited that is must be qualified as one of the dead provisions - at least inasmuch as it provides for a twelve-hour limit for animal tethering. Indeed, how can one verify this? To prove the commission of the misdemeanour, one would have to submit a video recording what was happening to an animal over this period of time, and the video would have to be over twelve hours long. Who, on what basis and using what funding should organise monitoring encompassing natural persons' backyards? The enforcement of this prohibition by public services appears impossible due to a shortage of human and financial resources; one can also hardly expect social organisations to carry out such supervision as unpaid volunteer work (aside from the issue of the legality of permanent observation and data collection). Thus, the prohibition of prolonged tethering of animals is unenforceable, and the legislator must have been aware of the factors referred to above. The legislator, then, must have known from the very beginning that the provision would have no actual impact on reality. In fact, the only relevant layer of this provision is its symbolic layer. Does this mean that it should be viewed negatively? Admittedly, provisions that only "threaten" with sanctions but in fact, cannot be effectively enforced potentially decrease the authority of law and can affect social obedience to norms. However, is it possible to ensure that animals are not tethered for extended periods of time in a manner other than through education and raising social awareness? It may be the case that over specific periods of time, symbols are the only tools the legislator has to influence reality.

\section{SYMBOLIC BAN ON THE USE OF ANIMALS IN CIRCUSES}

Another example of pro-animal measures worth discussing here is the increasingly issued bans on the organisation of circus shows with animals. The changes taking place in this sphere are so profound that they are likely to rebuild the foundations of our tradition. For decades, circuses using animals were totally acceptable and morally "safe". It was a commonly held belief that the circus was a right place for children, a place to see wild animals that love to show off their skills and potential. At that time, neither knowledge on animals nor knowledge on how they are trained for the circus was readily available - it only became shared with the society with the arrival of universal Internet access. In Poland, the objection to the use of animals in circus-

\footnotetext{
${ }^{29}$ According to CBOS research, Survey Report Dobre zmiany w ochronie prawnej zwierzat [Positive changes in the legal protection of animals], two-thirds of respondents (65\%) are in favour of introducing a provision that would prohibit keeping dogs chained.
} 
es is usually expressed through manifestations and Internet campaigns organized by non-governmental organisations ${ }^{30}$. Given the lack of activity on the part of the legislator in this regard ${ }^{31}$, local authorities of some communes took the lead, with their respective mayors issuing relevant ordinances. It should be noted, though, that these laws do not provide for a total ban on the organisation of circus shows on the territory of the commune, for there are no legal grounds for that. These ordinances are bans on supporting or allowing the organisation of circus shows with animals, for the communes are trying to exercise their property and management rights as regards their own property and property owned by the State Treasury. A typical ordinance of this type consists of two elements: first of all - the obligation for city or town officials to not make the property available "for purposes related to the organisation and holding of travelling circus shows having in their programme (repertoire) animals", and secondly - the prohibition for officials to sell tickets to circus shows with animals and to promote them using municipal assets ${ }^{32}$.

It should be noted at this point that these ordinances undoubtedly have potential to directly affect reality, for in many cases communes are owners and administrators of a considerable proportion of property situated within their administrative borders and in particular those intended for the organisation of mass events. Unfortunately, the prohibitions discussed here are assessed differently in case-law of administrative courts. While there are judgments where courts uphold communal bans on supporting the organisation of circus shows with animals ${ }^{33}$, in an equal - or perhaps even larger - proportion of jurisprudence these ordinances are considered to be issued in breach of the law ${ }^{34}$.

${ }^{30}$ In particular, the campaign and coalition „Animal-free circus”: https://www.cyrkbezzwierzat.pl, https://www.otwarteklatki.pl/cyrk-bez-zwierzat/ (Retrieved August 3, 2019). One of the first campaigns against circuses in Poland was launched in 1991 by Gaja Club (see Furtak 2016).

${ }^{31}$ It is worth noting that the ban on the use of animals in circus shows was one of the proposals of a revolutionary deputy's bill amending the Animal Protection Act, submitted to the Sejm on 6 November 2017 (file no. MK-020-751/17). The same bill also provided for introduction of a ban on keeping animals for fur, which attracted exceptional attention from the public. The bill, submitted by MPs from the then-parliamentary majority and publicly endorsed by the Chairman of the Law and Justice party (at least with respect to the ban on fur farming - see https://www.youtube.com/watch?v=i8c1WtyWZkQ), caused a stormy public debate and elicited vivid protests from entrepreneurs, including circus owners. And while the bill has not been assigned a Sejm paper number to this date, which means that the actual legislative works are yet to commence, it should be stressed that in the self-amendment of 3 January 2019 (file no. MK-020-751(10)/17) the authors resigned from the most controversial proposals, including the ban on organisation of circus shows with animals.

${ }^{32}$ Ordinance no. 521/2018/P of the Mayor of Poznań of 16 July 2018, http://bip.poznan.pl/bip/zarzadzenia-prezydenta/521-2018-p,k,521-2018-P/ (Retrieved August 10, 2019).

33 " (...), the Court cannot accept the argument of the petitioners that they were unlawfully excluded from potential lessees of municipal property (...) The contested ordinance did not reduce any rights of the petitioners as they were not entitled to any rights with respect to this property. The ordinance in question did not violate the freedom of economic activity carried out by the petitioners" - reads the final and binding judgment of the Voivodship Administrative Court in Gdańsk of 11 October 2016. See also the decision of the Supreme Administrative Court issued in this case on 5 April 2017, I OSK 27/17. 34 "According to the Court ruling on the case, a local government unit's decision, taken in the form of an 
The actual impact of bans on supporting the organisation of circus shows with animals is limited to the territory of a commune, or actually - to part of this territory, for it does not apply to property not owned or managed by the commune. Additionally, the real causative power of these bans can be lifted if the administrative court considers them illegal. What matters more than the real layer of these legal acts is, therefore, their symbolic layer. Through these acts, public administration authorities express their moral disapproval of the use of animals in circuses. What is more, the impact of this message can also transcend beyond the administrative borders of a commune - it appears that an official message issues by the authorities of Słupsk or Poznań can just as quickly stimulate discussion in Dębica or Nowa Sól, as evidenced by the growing number of similar prohibitions issued in other communes, encouraged by the regulations introduced earlier in other parts of the country ${ }^{35}$.

It is difficult to determine whether the communes that were first to have introduced the ban on supporting the organisation of circus shows with animals merely intended to take some symbolic measures. Regardless of the original intentions, the symbolic layer appears to be the dominant one - especially in view of its potential to transcend administrative borders of a specific commune. The symbolic character of the ordinances will be particularly visible in the next local government units that decide to issue such laws despite knowing that administrative courts are not always well disposed towards such legislation.

\section{CONCLUDING REMARKS}

The introduction of the Animal Protection Act into the Polish legal created a new situation where animals are protected due to their intrinsic value, and there is a requirement for their humane treatment in all spheres of life. It might seem as though the very enactment of the act was a significant step in humanitarian animal protection. In reality, however, the act is merely (or perhaps as much as) a confirmation of previously existing - which is not to say commonly acceptable - social, moral intuitions as to how animals should be treated. In particular, the act constitutes an attempt at defining certain necessary borders for our coexistence and determining acceptable ways and conditions of using animals for people's purposes, including economic and emotional ones. However, can provisions of the law themselves change the actual status of animals where one cannot resort to state compulsion? The society received an apparent signal from the legislator, but will this suffice? Can the legislator shape people's convictions in the right direction and change them without resorting to - adequate to

administrative act, that a specific group of entities whose activity, as the Court wishes to emphasise, is not prohibited by law, cannot apply for the possibility of concluding a communal property lease agreement, is in violation of the principle of freedom of economic activity, as laid down in the Constitution (...) and of the principle of equal treatment by public authorities" - reads the final and binding judgment of the Voivodship Administrative Court in Warsaw of 14 September 2016, I SA/Wa 604/16. See also the judgment of the Supreme Administrative Court issued in this case on 17 May 2017, I OSK 2937/16 and judgment of the Voivodship Administrative Court in Wrocław of 25 October 2016, II SA/Wr 372/16. 35 These types of bans are already in force in over 30 Polish towns and cities; the updated map is available at www.cyrkbezzwierzat.pl (Retrieved August 12, 2019). 
the aim - control and compulsion? The phenomenon of symbolic legislation ("good" symbolic legislation) appears to be indicative, at the very least, of the lawmakers' faith in their potential to influence the society in such a "soft" manner.

The examples analysed in the article were intended to show the vital role played by symbolic provisions in humanitarian protection of animals. In many cases, these provisions do not have a direct influence on the behaviours of their addressees and cannot forcefully impose certain practices. At the same time, they convey secure axiological messages that may indirectly affect social beliefs and convictions. The principle of dereification plays a central role in this regard. The provision laid down in Art. 1(1) of the Animal Protection Act does not impose any specific conduct; such conducts are, at most, a consequence of refining of the principle of dereification by the legislator in specific orders and prohibitions set forth further in the Animal Protection Act and other legal acts. The principle plays at least a threefold role, however: (1) emphasizes the intrinsic value of the life of each animal, (2) constitutes a particular model to which one should refer when interpreting detailed orders and prohibitions and (3) is an incentive for the community of law enforcers to continually think about the proper scope of humanitarian protection of animals - it opens discussion, gives it legitimacy, for example through the requirement to determine how to "respectively" apply provisions concerning things to animals. This will last until the legislator decides to otherwise, more precisely, determine the status of animals - after all, one could ask what they are, if they are no longer things and not yet entities.

It appears that the provision laid down in Art 1(1) of the Animal Protection Act, in the case of which the legislator consciously stopped at the symbolic layer and did not strive to give it any "real" character, Direct influence on how the addressees behave was supposed to be exerted by specific requirements and prohibitions established in the Animal Protection Act and other legal acts. However, in some cases, although specific conduct is indicated, it is impossible to issue adequate provisions for objective reasons. This can be due to factual restrictions, as in the case of the ban on keeping domestic animals tethered for over 12 hours, where the state apparatus does not have an adequate control mechanism. This may be a result of legal restrictions that, e.g. local governments trying to implement the ban on supporting the organisation of circus shows with animals are facing. In both cases, the fact that these provisions, indirectly at least, influence people's attitude towards animals and encourage self-reflection and discussion, should be recognised. What is interesting, it turns out that the symbolic dimension of legislation can be stronger than the real one, in that the power of the symbol is not confined by jurisdiction boundaries of the state or its administrative units.

In the last two cases, we have abstained from explicitly stating whether these provisions deserve to be labelled as good symbolic legislation. We see certain obstacles to that, for despite laudable goals and smaller or more significant social impact, these provisions can have a destructive influence on the perception of the law as such. In the case of keeping animals tethered, we are dealing with the establishment of an explicit penal sanction that will be perceived as an "empty threat". Meanwhile, in the case of the ban on supporting the organisation of circus shows with animals we can speak of 
exceeding of official powers, i.e. violation of the law - albeit it is not yet known which line of interpretation will prevail in the case-law of administrative courts.

The absence of protection of live fish against keeping and transport without sufficient amounts of water should be viewed negatively although the legislator explicitly prohibited this on pain of a considerable sanction - much higher than in the case of improper tethering of a domestic animal. What is more, it is difficult to see any actual restrictions to the enforcement of this ban. It, therefore, seems that the legislator did not intend to enact a provision deprived of the real layer - instead, the provision lost this layer in the practice of its application. Fortunately, the scale of activity on the part of non-governmental organisations in the period before Christmas and the consistency of such measures are clear signals that the provision will "be brought back to life" and will no longer be an example suitable for analysis using the concept of symbolic legislation.

FUNDING: This research received no external funding.

CONFLICT OF INTEREST: The authors declare no conflict of interest.

\section{REFERENCES}

Bańczyk, Wojciech. 2016. “’Miękkie prawo, ale prawo’, czyli o obowiązku przestrzegania soft law." Internetowy Przegląd Prawniczy TBSP UJ 1: 61-72.

Baum, Marsha L. 2011. “'Room on the Ark?': The Symbolic Nature of U.S. Pet Evacuation Statutes for Nonhuman Animals.” Pp. 105-118. in Considering Animals: Contemporary Studies in Human-Animal Relations, edited by C. Freeman, E. Leane and Y. Watt. Farnham: Ashgate.

Breczko, Anetta. 2013. “Od rzeczy do podmiotu. Praktyczne implikacje etyki ochrony zwierząt.” Białostockie Studia Prawnicze 14: 17-28.

Dwyer, John P. 1990. “The Pathology of Symbolic Legislation.” Ecology Law Quarterly 17(2): 233-316.

Furtak, Ewa. 2016. “Klub Gaja przekonuje: cyrk jest śmieszny, ale bez zwierząt.” Wyborcza 17.02.2016. Retrieved August 12, 2019 (http://bielskobiala.wyborcza.pl/ bielskobiala/1,88025,19615109,klub-gaja-od-lat-przekonuje-cyrk-jest-smieszny-ale-bez-zwierzat.html?disableRedirects=true).

Goettel, Mieczysław. 2013. Sytuacja zwierzęcia w prawie cywilnym. Warszawa: Wolters Kluwer Polska.

Jabłońska-Bonca, Jolanta. 1984. "Przesłanki stanowienia norm bez sankcji.” Ruch Prawniczy, Ekonomiczny i Socjologiczny XLVI(4): 151-167.

Koch, Larry W. and Galliher, John F. 1993. "Michigan's Continuing Abolition of the Death Penalty and the Conceptual Components of Symbolic Legislation.” Social \& Legal Studies 2(3): 323-346.

Łętowska, Ewa. 1997. "Dwa cywilnoprawne aspekty praw zwierząt: dereifikacja i personifikacja.” Pp. 71-92. in Studia z prawa prywatnego. Księga pamiątkowa ku czci Profesor Biruty Lewaszkiewicz-Petrykowskiej, edited by A. Szpunar. Łódź: Wy- 
dawnictwo Uniwersytetu Łódzkiego.

Matczak, Marcin. 2019. Imperium tekstu. Prawo jako postulowanie i urzeczywistnianie świata możliwego. Warszawa: Wydawnictwo Naukowe SCHOLAR.

Nazar, Mirosław. 2002. "Normatywna dereifikacja zwierząt - aspekty cywilnoprawne.” Pp. 129-151 in Prawna ochrona zwierząt, edited by M. Mozgawa. Lublin: Oficyna Wydawnicza VERBA.

Niesiołowski, Jarosław. 2017. “Leges imperfectae w prawie.” Gdańskie Studia Prawnicze XXXVIII: 593-600.

Nowacki, Józef. 2003. “'Odpowiednie’ stosowanie przepisów prawa.” Pp. 451-464 in Studia z teorii prawa, edited by J. Nowacki. Kraków: Zakamycze.

Pazdan, Maksymilian. 2012. "Podmioty stosunków cywilnoprawnych - zagadnienia ogólne.” Pp. 1021-1046. in System Prawa Prywatnego. Tom 1. Prawo cywilne - część ogólna, edited by M. Safjan. Legalis.

Probucka, Dorota. 2015. Prawa zwierząt. Kraków: UNIVERSITAS.

Scully, Jackie L. 2011. “'Choosing Disability', Symbolic Law, and the Media.” Medical Law International 11(3): 197-212.

Skuczyński, Paweł. 2008. "Soft law w perspektywie teorii prawa.” Pp. 325-343 in System prawny a porządek prawny, edited by O. Bogucki and S. Czepita. Szczecin: Wydawnictwo Naukowe Uniwersytetu Szczecińskiego.

Smolak, Marek. 2016. “Ustawy imitacyjne.” Ruch Prawniczy, Ekonomiczny i Socjologiczny LXXVIII (4): 31-39.

Stefaniuk, Małgorzata E. 2010. “Normatywność preambuły aktu normatywnego - doktryna a orzecznictwo.” Pp. 431-443 in Dyskrecjonalność $w$ prawie, edited by W. Staśkiewicz, T. Stawecki. Warszawa: LexisNexis.

Tushnet, Mark and Yackle, Larry. 1997. "Symbolic Statutes and Real Laws: The Pathologies of the Antiterrorism and Effective Penalty Act and the Prison Litigation Reform Act.” Duke Law Journal 47(1): 1-86.

van Klink, Bart. 2016. “Symbolic Legislation: An Essentially Political Concept.” Pp. 19-35 in Symbolic Legislation Theory and New Developments in Biolow, edited by B. van Klink, B. van Beers and L. Poort. Springer International Publishing.

Więckowska, Karolina. 2017. “Znęcanie się nad zwierzętami na gruncie ustawy o ochronie zwierząt - kilka refleksji de lege lata.” Pp. 150-165 in Sprawiedliwość dla zwierząt, edited by B. Błońska, W. Gogłoza, W. Klaus and D. Woźniakowska-Fajst. Warszawa: Instytut Nauk Prawnych Polskiej Akademii Nauk, Stowarzyszenie „Otwarte Klatki”.

Wróbel, Włodzimierz. 2009. “Czy powrót do racjonalizmu? Projekty nowelizacji kodeksu karnego w perspektywie zmian dokonanych w prawie karnym w latach 2005-2007.” Pp. 103-118 in Populizm penalny i jego przejawy w Polsce, edited by Z. Sienkiewicz and R. Kokot. Wrocław: Kolonia Limited as quoted in Nowak, Celina. 2014. Wpływ procesów globalizacyjnych na polskie prawo karne. LEX. 


\section{BIOGRAPHICAL NOTE}

Agnieszka Bielska-Brodziak is professor of law at the University of Silesia in Katowice, Poland.

Marlena Drapalska-Grochowicz is PhD student of law at the University of Silesia in Katowice, Poland.

Marek Suska is PhD student of law at the University of Silesia in Katowice, Poland.

OPEN ACCESS: This article is distributed under the terms of the Creative Commons Attribution Non-commercial License (CC BY-NC 4.0) which permits any non-commercial use, and reproduction in any medium, provided the original author(s) and source are credited.

ARTICLE HISTORY: Received 2019-09-04 / Accepted 2019-11-26 
